\title{
The burden of overweight and its risk factors in urban Nepalese school adolescents: A cross- sectional study
}

Kamal Chaulagain ( $\square$ kamal.chaulagain123@gmail.com )

\section{Research}

Keywords: overweight, risk factors in urban Nepalese school adolescents

Posted Date: May 20th, 2020

DOI: https://doi.org/10.21203/rs.3.rs-28845/v1

License: (a) (i) This work is licensed under a Creative Commons Attribution 4.0 International License.

Read Full License

Version of Record: A version of this preprint was published at Journal of Quality in Health Care \& Economics on January 1st, 2021. See the published version at https://doi.org/10.23880/jqhe-16000230. 


\section{Abstract}

Introduction Adolescents overweight are rising in both developing and developed countries. Overweight and obese adolescents are more likely to become obese adults which stimulate the risk of Noncommunicable diseases such as diabetes, cardiovascular diseases and so on. Adolescence is the critical period for development of unhealthy life styles and food choices which increases the risk of NCDs. The loss of productivity, premature deaths and disability has been associated with NCDs at younger ages. This study focuses on identifying the prevalence and associated risk factors with adolescents overweight.

Methods A school based cross-sectional study was conducted in Gokarneshwor municipality of Nepal. A random sample of 558 students aged 10-19 years from nine schools was included in the study. A selfadministered questionnaire was filled out by the study participants. Anthropometric indices were measured and categorized using BMI for age Z-score. Descriptive statistics were carried out. Variables were considered for multivariable logistic regression if a Wald test $p$-value was $\leq 0.25$ during bivariate logistic regression. The odds ratio with a $95 \% \mathrm{Cl}$ was calculated and a $\mathrm{p}$-value of $\leq 0.05$ was considered to declare the statistical significance of variables after fitting into the multivariable logistic regression.

Results The prevalence of overweight among school adolescents was $17.9 \%$ (95\% $\mathrm{Cl} 14.7$ to 21.1 ). The female adolescents were more likely to get overweight as compared to male adolescents (AOR 1.53, $95 \%$ $\mathrm{Cl} 0.97$ to 2.39). Similarly, the adolescents staying with more than four family members were less likely to get overweight as compared to their counterparts (AOR 0.57, 95\% Cl 0.35 to 0.95 ). There was no statistical significant association between adolescent overweight and age group, family type, school type, mothers' occupation or fruits consumption.

Conclusion The study findings highlighted the accelerated increase in the prevalence of overweight among school adolescents in Nepal. Therefore, appropriate nutritional intervention focusing on tackling overweight should be formulated and implemented so that the prevalence of overweight-associated noncommunicable diseases can be minimized.

\section{Introduction}

The burden of overweight and obesity among adolescents had been a major public health problem in the world. Previously it was considered to be the problem of developed world, however, prevalence of overweight and obesity has increased in recent years at developing countries like Nepal. Although overweight and obesity has become pandemic even in developing countries, it has been a most neglected issue $^{1}$. Globally, overweight has nearly tripled since 1975 with more than 340 million children and adolescents aged 5-19 years being overweight in $2016^{2}$. The overweight and obesity is estimated that around $30 \%$ of all children will be obese or overweight by $2030^{3}$. The recent report shows that maximum numbers of overweight children are in developing countries with higher rate of increment than as 
compared to developed world ${ }^{3}$. The overweight and obesity has been elevated in most countries in an alarming rate despite of the economies of the countries ${ }^{4}$. The rise in overweight and obesity can be attributable to change in life style related factors such as physical activity and dramatic change in dietary intake pattern of adolescents ${ }^{5}$. Overweight and obesity stimulates non-communicable diseases (NCDs) such as high blood pressure, high cholesterol, elevated blood glucose and cardio-vascular diseases ${ }^{6}$. The World Health Organization Global Status Report (GSR) reported that NCDs were responsible for 38 million (68\%) of the world's 56 million deaths in 2012 of which one quarter deaths in low and middle income countries ${ }^{7}$.

Adolescents comprise of around $16 \%$ of the world's total population ${ }^{8}$. In Nepal these population comprise of around one fourth (24\%) of the total population ${ }^{9}$. The period of adolescence (10-19 years) is a time of considerable physiological, physical and behavioral changes ${ }^{10,11}$. It is a crucial stage of life span in which adolescents tends to adopt unhealthier lifestyles and food behavior which may have deleterious effects on their health. Studies suggest that overweight adolescents are likely to be overweight adults ${ }^{12}$,

${ }^{13}$. It is estimated that adolescent overweight will increase future adult obesity by $5-15 \%$ by $2035^{14}$. The recent increase in adolescent obesity will direct to huge cost in future ranging from productivity loss to premature deaths and disability among adolescents ${ }^{15}$.

Overweight and obesity among adolescents have been neglected mostly in low and middle income countries assuming that these age groups are herds of healthy population. Further, it is noted that there are limited studies and consequently grossly inadequate information regarding overweight among adolescents. Thus, this study aimed to discover the prevalence and associated factors of overweight among adolescents which will bridge the knowledge and information gap in this area with potentiality to design policy and program appropriately.

\section{Methods}

Study Design, Sample size and population

This is a school based cross-sectional study, which was conducted in the Gokarneshwor municipality, in the north east of Kathmandu, between August 2019 and October 2019. The total number of adolescent students studying in both private and community schools in Gokarneshwor municipality was 18557 students (2019). A multistage random sampling technique was adopted to select the study participants. The list of private and community schools were obtained from the education, sports and youth section of the municipality. Among the total 90 schools, 7 private (out of 75) and 2 community (out of 15) schools were selected randomly using probability proportionate to size sampling method. In the next stage, equal numbers of participants were enrolled from all nine schools. A total of 558 school adolescents were included in the study with their self-administered responses and anthropometric measurement. The inclusion criterion was school adolescents who are able to stand for measure of health and weight. 
The study permission was obtained from the municipal education, sports and youth section. Then the researcher visited the chosen schools to inform them about the research. Data were collected using a self-administered, pretested and structured questionnaire. The measurement of weight and height were obtained as per WHO guidelines using a SECA digital weighing scale and Shorr-board respectively. The accuracy of the weighing scale and Shorr-board were checked using the standard weight and height at the beginning of every data collection session and after measurement of every ten students. The questionnaire was designed to gather personal, socio-demographic, nutritional and life-style information about study participants.

Statistical Analysis

Data entry was done in Epi-Info version 7 and for anthropometic calculation, WHO Anthroplus software V.1.0.4 was used. Body mass index (BMI) for age Z-score were calculated for identifying the overweight individuals. Adolescents whose BMI for age Z-score was above +1SD from the median of the WHO reference population were classified as overweight ${ }^{16}$. The age of the participants were calculated using date of birth reported by adolescents and date of data collection. STATA MP 13 software was used for the statistical analysis. Bivariate and multivariate binary logistic regression analyses were conducted to determine the association between dependent (overweight) and independent (risk factors) variables. In the beginning, for bivariate analysis, a single variable at a time was entered; unadjusted OR and $95 \% \mathrm{Cl}$ were computed for all independent variables. The Wald test $p$-value from the bivariate analysis was checked and $p$-value less than 0.25 were taken to the final model ${ }^{17}$. Multicollinearity was checked before taking the variable to final model. It was done among the variables observing the variance inflation factor (VIF) and variables having VIF less than 2 were then included in the final model. Multivariate analyses with all independent variables were entered at the same time to adjust the effect of confounding, and adjusted OR and $95 \% \mathrm{Cl}$ were computed. Statistical significance was considered with the $p$-value $(p>0.05)$.

\section{Ethical Consideration}

The ethical approval for the study was obtained from Institutional Review Committee, Patan Academy of Health Sciences, Nepal. The study was conducted with prior permission from the municipal authorities and school administration. Informed consent and/or assent were obtained from the study participants prior to the data collection. The study objectives and benefits were shared with the school adolescents. The study participants were assured for confidentiality of the information at all levels of the study by avoiding personal identifiers. After the data collection, the researcher explained the school adolescents about the nutritional problems, their causes, consequences and preventive measures.

\section{Results}

The prevalence of overweight among school adolescents was $17.9 \%$ ( $95 \% \mathrm{Cl} 14.7$ to 21.1 ). Table 1 represents the general characteristics of the school adolescents. The mean \pm SD of the age was $13.5 \pm$ 
2.1 years and $51.2 \%$ were females. The mean weight and height of the adolescents were found to be $45.29 \pm 10.78 \mathrm{~kg}(95 \% \mathrm{Cl} 44.3-46.1)$ and $151.09 \pm 10.07 \mathrm{~cm}(95 \% \mathrm{Cl} 150.2-151.9)$ respectively.

The bivariate analysis (Table 2) showed that three variables were independently associated with the overweight. The sex of the participants, family size and mothers' education were statistically significantly associated with overweight. However, school type, mothers' occupation, playing games or watching TV, family type, age groups, meal consumption and fruits consumption were not statistically significant. The variables with Wald test $p$-value $<0.25$ were considered in the final model. The multivariate logistic regression analyses (Table 2) was fitted between sex, family type, family size, occupation and hours spent in playing games in mobile or watching TV. The mothers' education variable was dropped due to multicollinearity. The female adolescents were more likely to get overweight as compared to male adolescents (AOR $1.53,95 \% \mathrm{Cl} 0.97$ to 2.39 ) holding constant for other variables. Similarly, the adolescents staying with more than four family members were less likely to get overweight as compared to their counterparts ( $A O R=.57,95 \% \mathrm{Cl} 0.35$ to 0.95 ) controlling for other variables.

\section{Table 1: General characteristics of school adolescents}

$\mathrm{N}=558$ 


\begin{tabular}{|c|c|c|}
\hline Characteristics & Frequency & Percentage \\
\hline \multicolumn{3}{|l|}{ Sex } \\
\hline Male & 272 & 48.75 \\
\hline Female & 286 & 51.25 \\
\hline \multicolumn{3}{|l|}{ Age group } \\
\hline 10-13 (early adolescents) & 289 & 51.79 \\
\hline 14-16 (middle adolescents) & 221 & 39.61 \\
\hline 17-19 (late adolescents) & 48 & 8.60 \\
\hline \multicolumn{3}{|l|}{ School type } \\
\hline Community (Government) & 124 & 22.22 \\
\hline Private & 434 & 77.78 \\
\hline \multicolumn{3}{|l|}{ Birth Order } \\
\hline $1^{\text {st }}$ & 257 & 46.06 \\
\hline $2^{\text {nd }}$ & 168 & 30.11 \\
\hline $3^{\text {rd }}$ & 80 & 14.34 \\
\hline $4^{\text {th }}$ & 32 & 5.73 \\
\hline $5^{\text {th }}$ and above & 21 & 3.76 \\
\hline \multicolumn{3}{|l|}{ Family type } \\
\hline Nuclear & 422 & 75.63 \\
\hline Joint/Extended & 136 & 24.37 \\
\hline \multicolumn{3}{|l|}{ Veg/Non-veg } \\
\hline Vegetarian & 61 & 10.93 \\
\hline Non-Vegetarian & 497 & 89.07 \\
\hline \multicolumn{3}{|l|}{ Meals Consumption } \\
\hline$\leq 3$ times/day & 255 & 45.70 \\
\hline >3 times/day & 303 & 54.30 \\
\hline \multicolumn{3}{|c|}{ Fruits Consumption in last week } \\
\hline Yes & 389 & 69.71 \\
\hline
\end{tabular}


Table 2: Factors associated with overweight among school adolescents in Nepal 
Characteristics

\section{Overweight}

Yes

100

(17.92\%)

No

Unadjusted

OR

458

(82.08\%)

Sex

Male

Female

40

(14.71\%)

60

(20.98\%)

Wald test

1

232

(85.29\%)

226

$1.53\left(0.99 \quad 0.05^{\star}\right.$
to 2.39$)$
Adjusted $\begin{array}{ll}\mathrm{p}^{-} & \\ \text {value } & \mathrm{OR}\end{array}$ pvalue

\begin{tabular}{|c|c|c|c|c|c|c|}
\hline Female & $\begin{array}{l}60 \\
(20.98 \%)\end{array}$ & $\begin{array}{l}226 \\
(79.02 \%)\end{array}$ & $\begin{array}{l}1.53(0.99 \\
\text { to } 2.39)\end{array}$ & $0.05^{\star}$ & $\begin{array}{l}1.53 \\
(0.97 \text { to } \\
2.39)\end{array}$ & $0.05^{\star}$ \\
\hline Family Type & & & Wald test & 0.25 & & \\
\hline Nuclear & $\begin{array}{l}80 \\
(18.96 \%)\end{array}$ & $\begin{array}{l}342 \\
(81.04 \%)\end{array}$ & 1 & & 1 & \\
\hline Joint/Extended & $\begin{array}{l}20 \\
(14.71 \%)\end{array}$ & $\begin{array}{l}116 \\
(85.29 \%)\end{array}$ & $\begin{array}{l}0.73(0.43 \\
\text { to } 1.25)\end{array}$ & 0.25 & $\begin{array}{l}1.02(0.54 \\
\text { to } 1.83)\end{array}$ & 0.99 \\
\hline Family Size & & & Wald test & 0.02 & & \\
\hline$\leq 4$ members & $\begin{array}{l}56 \\
(22.05 \%)\end{array}$ & $\begin{array}{l}198 \\
(77.95 \%)\end{array}$ & 1 & & 1 & \\
\hline$>4$ members & $\begin{array}{l}44 \\
(14.47 \%)\end{array}$ & $\begin{array}{l}260 \\
(85.53 \%)\end{array}$ & $\begin{array}{l}0.59(0.38 \\
\text { to } 0.92)\end{array}$ & $0.02^{*}$ & $\begin{array}{l}0.57 \\
(0.35 \text { to } \\
0.95)\end{array}$ & $0.03^{*}$ \\
\hline Mothers Occupation & & & Wald test & 0.23 & & \\
\hline Household work & $\begin{array}{l}52 \\
(20.00 \%)\end{array}$ & $\begin{array}{l}208 \\
(80.00 \%)\end{array}$ & 1 & & 1 & \\
\hline Outside Home & $\begin{array}{l}48 \\
(16.11 \%)\end{array}$ & $\begin{array}{l}250 \\
(82.89 \%)\end{array}$ & $\begin{array}{l}0.76(0.49 \\
\text { to } 1.18)\end{array}$ & 0.23 & $\begin{array}{l}0.74 \\
(0.48 \text { to } \\
1.15)\end{array}$ & 0.19 \\
\hline $\begin{array}{l}\text { Watching TV or playing } \\
\text { games on computer }\end{array}$ & & & Wald test & 0.15 & & \\
\hline$>2$ h/day & $\begin{array}{l}84 \\
(19.09 \%)\end{array}$ & $\begin{array}{l}356 \\
(80.91 \%)\end{array}$ & 1 & & 1 & \\
\hline$\leq 2$ h/day & $\begin{array}{l}16 \\
(13.56 \%)\end{array}$ & $\begin{array}{l}102 \\
(86.44 \%)\end{array}$ & $\begin{array}{l}0.66(0.37 \\
\text { to } 1.18)\end{array}$ & 0.16 & $\begin{array}{l}0.72 \\
(0.40 \text { to } \\
1.29)\end{array}$ & 0.27 \\
\hline Mothers' Education & & & Wald test & 0.007 & & \\
\hline No education & $\begin{array}{l}42 \\
(19.00 \%)\end{array}$ & $\begin{array}{l}179 \\
(81.00 \%)\end{array}$ & $\begin{array}{l}0.26(0.09 \\
\text { to } 0.72)\end{array}$ & $0.01^{* *}$ & & \\
\hline Primary & 14 & 118 & $0.13(0.04$ & $0.00 * \star$ & & \\
\hline
\end{tabular}




\begin{tabular}{|c|c|c|c|c|}
\hline & (10.61\%) & (89.39\%) & to 0.40 ) & \\
\hline Secondary & $\begin{array}{l}30 \\
(20.27 \%)\end{array}$ & $\begin{array}{l}118 \\
(79.73 \%)\end{array}$ & $\begin{array}{l}0.28(0.10 \\
\text { to } 0.80)\end{array}$ & $0.01^{* *}$ \\
\hline Higher Secondary & $6(15.00 \%)$ & $\begin{array}{l}34 \\
(85.00 \%)\end{array}$ & $\begin{array}{l}0.19(0.05 \\
\text { to } 0.72)\end{array}$ & $0.01^{* *}$ \\
\hline University & $8(47.06 \%)$ & $\begin{array}{l}9 \\
(52.94 \%)\end{array}$ & 1 & \\
\hline Age group & & & Wald test & 0.42 \\
\hline 10-13 years & $\begin{array}{l}50 \\
(17.30 \%)\end{array}$ & $\begin{array}{l}239 \\
(82.70 \%)\end{array}$ & 1 & \\
\hline $14-16$ years & $\begin{array}{l}44 \\
(19.91 \%)\end{array}$ & $\begin{array}{l}177 \\
(80.09 \%)\end{array}$ & $\begin{array}{l}1.18(0.75 \\
\text { to } 1.86)\end{array}$ & 0.45 \\
\hline 17-19 years & $6(12.50 \%)$ & $\begin{array}{l}42 \\
(87.50 \%)\end{array}$ & $\begin{array}{l}0.68(0.27 \\
\text { to } 1.69)\end{array}$ & 0.41 \\
\hline School Type & & & Wald test & 0.38 \\
\hline Government (Community) & $\begin{array}{l}19 \\
(15.32 \%)\end{array}$ & $\begin{array}{l}105 \\
(84.68 \%)\end{array}$ & 1 & \\
\hline Private & $81(18.66 \%)$ & $\begin{array}{l}353 \\
(81.34 \%)\end{array}$ & $\begin{array}{l}1.26(0.73 \\
\text { to } 2.18)\end{array}$ & 0.39 \\
\hline Meals consumption & & & Wald test & 0.55 \\
\hline$\leq 3$ times/day & $\begin{array}{l}43 \\
(16.86 \%)\end{array}$ & $\begin{array}{l}212 \\
(83.14 \%)\end{array}$ & 1 & \\
\hline$>3$ times/day & $\begin{array}{l}57 \\
(18.81 \%)\end{array}$ & $\begin{array}{l}246 \\
(81.19 \%)\end{array}$ & $\begin{array}{l}1.14(0.73 \\
\text { to } 1.76)\end{array}$ & 0.55 \\
\hline Fruits Consumption & & & Wald test & 0.81 \\
\hline$<3$ times/week & $82(18.10 \%)$ & $\begin{array}{l}371 \\
(81.90 \%)\end{array}$ & 1 & \\
\hline$\geq 3$ times/week & $\begin{array}{l}18 \\
(17.14 \%)\end{array}$ & $\begin{array}{l}87 \\
(82.86 \%)\end{array}$ & $\begin{array}{l}0.93(0.53 \\
\text { to } 1.64)\end{array}$ & 0.81 \\
\hline
\end{tabular}

${ }^{*} \mathrm{p}<0.05 ;{ }^{* *} \mathrm{p}<0.01$

\section{Discussion}

The mean BMI-for-age Z- scores of the study populations was found to be 0.017 SD. The prevalence of overweight was $17.9 \%$ which is higher than the similar study conducted in Nepal which reported $12.2 \%$ overweight among 16-19 years adolescents ${ }^{18}$. Similarly, the prevalence of overweight in this study is 
greater than the findings from study done in Kaski district which reported 8.1\% prevalence of overweight among school adolescents ${ }^{19}$. The study from Pakistan, India and China showed lower prevalence of overweight among adolescents than this study $20-24$.

Figure 1 shows the comparison of the BMI for age index curves of the study population when compared with reference curves proposed by the World Health Organization. School adolescents in the present study showed, in general, lower values for BMI for age index, when compared to the analyzed reference points.

Figure 1: Comparison of the growth curve of school adolescents with the World Health Organization (WHO) curve, according to BMl for age index.

In this study, the female adolescents were found to be more overweight as compared to the male adolescents. This might be because of physical inactivity among adolescent girls compared to the boys. Boys tend to get engaged with sports and extracurricular activities than boys. However a study conducted in Nepal showed adolescent boys were three times more likely to get overweight than their counterparts ${ }^{18}$. Adolescents staying with more than four family members were less likely to get overweight as compared to those who stay with less than four family members.

The present study showed that there is no significant association between overweight and school type and mothers' occupation. However, the study conducted in Nepal showed that school type and mothers' occupation were significantly associated with overweight among adolescents ${ }^{18,19}$.

\section{Conclusion}

There is a substantial burden of adolescent overweight in Nepal. This study shows the higher prevalence of overweight among school adolescents in a municipality of Nepal. Action needs to be taken to curb the problem of overweight among school adolescents. Comprehensive urban-based campaigns for its prevention and control should be launched at earliest to tackle this problem.

\section{Declarations}

Ethics approval and consent of participant: The ethical approval was obtained from Institutional Review Committee, Patan Academy of Health Sciences, Nepal. The Gokarneshwor municipality education sports and youth section provide approval for data collection at school. The informed written assent and/or consent were taken from the participants.

Consent for Publication: I provide consent to the journal for the publication of this manuscript.

Availability of data and methods: No additional data are available. 
Competing interests: No.

Funding: This research received no specific grant from any funding agency in the public, commercial or not-for-profit sectors.

Authors Contribution: Not Applicable

Acknowledgements: I would like to thank all the participants, municipal authorities and schools of Gokarneshwor municipality for their support in data collection.

Authors' Information: The author is a MPH graduate from Patan Academy of Health Sciences and is involved with research activities in Nepal.

\section{References}

1. Delisle H, Chandra-Mouli V, Benoist B. Should adolescents be specifically targeted for nutrition in developing countries? To address which problems, and how? In 1998. p. 2-38.

2. World Health Organization. [cited 2019 December 30] Available from: https://www.who.int/newsroom/fact-sheets/detail/obesity-and-overweight

3. Mazidi M, Banach M, Kengne AP. Prevalence of childhood and adolescent overweight and obesity in Asian countries: A systematic review and metaanalysis. Arch Med Sci. 2018;14(6):1185-203.

4. Bhurosy T, Jeewon R. Overweight and obesity epidemic in developing countries: A problem with diet, physical activity, or socioeconomic status? Sci World J. 2014;2014.

5. Maryam Bahreynian, Zamzam Paknahad and MRM. Major Dietary Patterns and Their Associations with Overweight and Obesity Among Iranian Children. Int J Prev Med . 2013;4(4):448-58. Available from: https://www.ncbi.nlm.nih.gov/pmc/articles/PMC3650598/

6. Wagner $\mathrm{KH}$, Brath $\mathrm{H}$. A global view on the development of non communicable diseases. Preventive medicine. 2012 May 1;54:S38-41.

7. World Health Organization. Global status report on noncommunicable diseases 2014 . World Health Organization; 2014.

8. Gibbons JL, Poelker KE. in a Cross-Cultural Perspective. Cross-Cultural Psychology: Contemporary Themes and Perspectives. 2019 Apr 1:190.

9. Central Bureau of Statistics. National Population and Housing Census 2011. Available from: https://unstats.un.org/unsd/demographic-social/census/documents/Nepal/Nepal-Census-2011Vol1.pdf

10. Yurgelun-Todd D. Emotional and cognitive changes during adolescence. Current opinion in neurobiology. 2007 Apr 1;17(2):251-7.

11. Nepal Health Research Council. Adolescent Nutrition Survey in Nepal. 2014. Available from: http://nhrc.gov.np/wp-content/uploads/2017/07/latest-final-nutrition-book.pdf 
12. Whitaker RC, Wright JA, Pepe MS, Seidel KD, Dietz WH. Predicting obesity in young adulthood from childhood and parental obesity. N Engl J Med. 1997;337(13):869-873

13. Freedman DS, Khan LK, Serdula MK, Dietz WH, Srinivasan SR, Berenson GS. The relation of childhood BMI to adult adiposity: the Bogalusa Heart Study. Pediatrics. 2005;115(1):22-27.

14. Bibbins-Domingo K, Coxson P, Pletcher MJ, Lightwood J, Goldman L. Adolescent overweight and future adult coronary heart disease. N Engl J Med. 2007;357(23):2371-2379

15. Lightwood J, Bibbins-Domingo K, Coxson P, Wang YC, Williams L, Goldman L. Forecasting the future economic burden of current adolescent overweight: an estimate of the coronary heart disease policy model. American journal of public health. 2009 Dec;99(12):2230-7.

16. WHO Anthro Plus for personal computers Manual: Software for assessing growth of the world's children and adolescents. Geneva: WHO, 2009 Available from: https://www.who.int/growthref/tools/who_anthroplus_manual.pdf

17. Hosmer DW. lemeshow S. Applied logistic regression. New York. 2000.

18. Piryani S, Baral KP, Pradhan B, et al Overweight and its associated risk factors among urban school adolescents in Nepal: a cross-sectional studyBMJ Open 2016;6:e010335. doi: 10.1136/bmjopen2015-010335

19. Acharya B, Chauhan HS, Thapa SB, Kaphle HP, Malla D. Prevalence and sociodemographic factors associated with overweight and obesity among adolescents in Kaski district, Nepal. Indian J Community Heal. 2015;26(April 2015):118-22.

20. Gurung TR, VI NG. Overweight and Obesity among the Adolescent School Students in Belgaum City. J Nepal Med Assoc. 2014;52(9):791-5. Available from: https://doi.org/10.31729/jnma.1876

21. Rani MA, Sathiyasekaran BWC. Behavioural Determinants for Obesity : A Cross-sectional Study Among Urban Adolescents in India. J Prev Med Public Heal. 2013;46:192-200.

22. Bengal W, Bengal W. Overweight and Obesity among Urban Bengalee Early Adolescent School Girls of Overweight and Obesity among Urban. Iran J Pediatr. 2015;23(April 2013):237-46. Available from: http://ijp.tums.ac.ir

23. Ahmed J, Laghari A, Naseer M, Mehraj V. Prevalence of and factors associated with obesity among Pakistani schoolchildren : a school-based, cross-sectional study. East Mediterr Journa. 2013;19(3).

24. Guo X, Zheng L, Li Y, et al. Prevalence and risk factors of being overweight or obese among children and adolescents in northeast China. Pediatr Res 2013;74:443-9. doi:10.1038/pr.2013.116

\section{Figures}




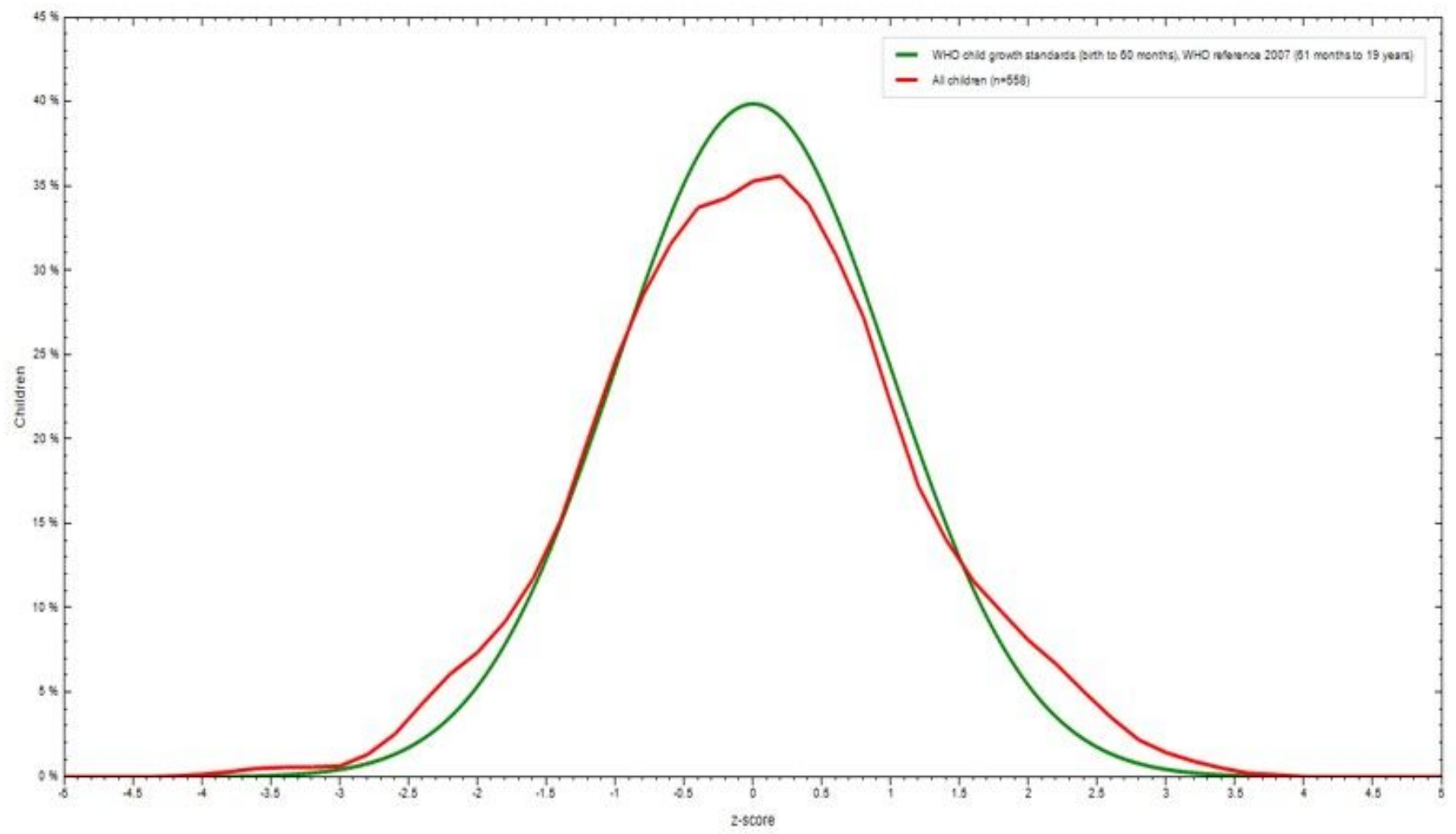

Figure 1

Comparison of the growth curve of school adolescents with the World Health Organization (WHO) curve, according to $\mathrm{BMI}$ for age index. 